\title{
Nitrogen Fertilization on Maize Sowing: Plant Growth and Seed Vigor
}

\author{
Cristian Troyjack, João Roberto Pimentel, Ítala Thaísa Dubal Padilha, \\ Ruddy Alvaro Veliz Escalera, Lanes Beatriz Acosta Jaques, Felipe Koch, \\ Manoela Andrade Monteiro, Gustavo Henrique Demari, Vinicius Jardel Szareski, \\ Ivan Ricardo Carvalho, Luis Osmar Braga Schuch, Tiago Zanatta Aumonde, Tiago Pedó
}

Federal University of Pelotas, Capão do Leão, Brazil

Email: cristiantroyjack@hotmail.com

How to cite this paper: Troyjack, C., Pimentel, J.R., Padilha, Í.T.D., Escalera, R.A.V., Jaques, L.B.A., Koch, F., Monteiro, M.A., Demari, G.H., Szareski, V.J., Carvalho, I.R., Schuch, L.O.B., Aumonde, T.Z. and Pedó, T. (2018) Nitrogen Fertilization on Maize Sowing: Plant Growth and Seed Vigor. American Journal of Plant Sciences, 9, 83-97.

https://doi.org/10.4236/ajps.2018.91008

Received: November 22, 2017

Accepted: January 14, 2018

Published: January 17, 2018

Copyright $\odot 2018$ by authors and Scientific Research Publishing Inc. This work is licensed under the Creative Commons Attribution International License (CC BY 4.0).

http://creativecommons.org/licenses/by/4.0/ CC) (i) Open Access

\begin{abstract}
The management of fertilization in maize plants is a preponderant factor in the search for higher yields and obtaining quality seeds. In this sense, the study of nitrogen $(\mathrm{N})$ management is predominant in improving the efficiency of its application. The objective of this study was to evaluate the growth, partition assimilation and vigor expression of maize seeds submitted at different doses of nitrogen applied at sowing. The treatments were constituted by different doses of nitrogen fertilization at sowing, being: $25 \%, 50 \%, 75 \%$ and $100 \%$ of the recommended dose for the crop, according to the recommendation of nitrogen fertilization. The plants were collected at regular intervals of 21 days after sowing until the end of the growth cycle. For the analysis of growth and partition of dry matter between the organs, the accumulation of dry matter and leaf area was measured. The experimental design was randomized blocks in a $4 \times 7$ factorial scheme (four $\mathrm{N}$ rates at sowing and seven collection times with three replications). The maize plants under the influence of nitrogen fertilization at sowing presented differential growth and distinct responses in the assimilated partition between their structures, with the intensity dependent on the dose used. Plants grown using $75 \%$ of the recommended dose of $\mathrm{N}$ at sowing had a higher relative growth rate, with more pronounced effects compared to the other doses. The expression of maize seed vigor increases to an increase of $82.5 \% \mathrm{~N}$ at sowing.
\end{abstract}

\section{Keywords}

Emergence Speed, Net Assimilation Rates, Relative Growth Rates, Zea mays L., Vigor 


\section{Introduction}

Maize (Zea mays) is a plant whose origin is believed to have occurred in Mexico and was later spread by pre-Columbian peoples to the other continents [1]. The productivity of this cereal is dependent on the cultivar, soil, fertilization, climate, cultural practices, pests and diseases [2] [3]. Therefore, it is important and necessary to develop studies in an attempt to solve the various problems that involve these factors, seeking high outputs with high quality.

With regard to cultural practices, the management of fertilization is a preponderant factor in the search for higher yields and the obtaining of quality seeds. In this sense, nitrogen $(\mathrm{N})$ management has been one of the most widely studied agricultural practices in the search to improve its efficiency of use. Different concentrations of nutrients affect the growth of cereals [4] [5], while an adequate supply of these elements favors the productivity of the maize [6]. $\mathrm{N}$ is one of the main plant nutrients, being required in large quantities [7].

The proper application of nutrients to the soil is an important factor that interferes with maize yield, microorganism activity and soil quality improvement. The proper application of nutrients to the soil is an important factor that interferes with crop yield, microorganism activity and soil quality improvement. This necessity exists because most of the $\mathrm{N}$ in the soil is in organic combinations, and this form is unavailable to the plants and, in general, the soil does not fulfill the demand of the crop in terms of $\mathrm{N}$ [8]. Therefore, to obtain higher yields of maize it is necessary to apply nitrogenous fertilizers.

Nitrogen is important in plant metabolism when participating in several metabolic routes of great importance to plants [9]. Research indicates that high concentrations of $\mathrm{N}$ in the root zone are beneficial in promoting rapid initial plant growth and increased grain yield [10]. In addition, the supply of $\mathrm{N}$ in the early stages favors a higher absorption of phosphorus [11], thereby facilitating the growth of plants.

Growth analysis is a technique that allows the primary and physiological bases of production to be determined, describing at plant differential responses of different time intervals that are related to morphophysiological conditions under different environmental and management conditions [12]. In turn, vigor is a component of the physiological quality of seeds related to the reorganization of the cell membrane system, hydrolysis, translocation and reserve allocation, and can be determined from the emergence of seedlings [13]. Therefore, the joint evaluation of the growth and expression of seed vigor makes it possible to evaluate the level of influence imposed by the factor studied.

In this sense, the objective of this research was to analyze comparatively the growth of plants and the vigor of maize seeds produced under the influence of different doses of nitrogen at sowing.

\section{Materials and Methods}

The experiment was conducted in the experimental area of the Department of 
Plant Sciences of the Federal University of Pelotas-Capão do Leão, RS ( $31^{\circ} 52^{\prime} \mathrm{S}$ and $\left.52^{\circ} 21^{\prime} \mathrm{W}\right)$. The determination of seed vigor was carried out in a germination chamber which control temperature and relative humidity. For the establishment of the crop, seeds of the yellow maize genotype were used, with a germination of $95 \%$.

The sowing was done manually in January 2017, in soil classified as Planosols Hydromorphic. The spacing between lines and between plants was 45 and 36 centimeters, respectively, resulting in a population density of 55,000 ha ${ }^{-1}$ plants [14].

Soil correction was performed according to previous analysis and according to the recommendation of the Manual of Fertilization and Liming for the Rio Grande do Sul and Santa Catarina States [15]. Each plot consisted of four rows of 6 meters in length, and the two rows were considered for the plot area.

The soil of the experiment site is classified as Solubic Eucalyptus Haplic Planosol, belonging to the Pelotas mapping unit [16]. The results of the soil analysis showed the following chemical and physical characteristics: $\mathrm{pH}\left(\mathrm{H}_{2} \mathrm{O}\right): 5.0 ; \mathrm{P}$ : $46.0 \mathrm{mg} \cdot \mathrm{dm}^{-3}$; K: $53 \mathrm{mg} \cdot \mathrm{dm}^{-3}$; S: $19.8 \mathrm{mg} \cdot \mathrm{dm}^{-3}$; Ca: $3.2 \mathrm{cmolc} \cdot \mathrm{dm}^{-3} ; \mathrm{Mg}: 0.9$ cmolc. $\mathrm{dm}^{-3}$; Al: 0.8 cmolc $\cdot \mathrm{dm}^{-3}$; B: $0.0 \mathrm{mg} \cdot \mathrm{dm}^{-3}$; Cu: $1.4 \mathrm{mg} \cdot \mathrm{dm}^{-3} ; \mathrm{Zn}: 1.8$ $\mathrm{mg} \cdot \mathrm{dm}^{-3}$; Mn: $14.2 \mathrm{mg} \cdot \mathrm{dm}^{-3}$; Na: $50 \mathrm{mg} \cdot \mathrm{dm}^{-3}$; CTC: $5.3 \mathrm{cmolc} \cdot \mathrm{dm}^{-3}$; base saturation: $45 \%$; organic matter: $2.07 \%$; clay: $19 \%$. During the experiment, temperature, solar radiation, relative air humidity and rainfall values were recorded (Figure 1).

The treatments comprised different doses of nitrogen fertilization at sowing, those being $25 \%, 50 \%, 75 \%$ and $100 \%$ of the recommended dose of the crop, which was $30 \mathrm{~kg} \mathrm{~N} \mathrm{ha}^{-1}$, in accordance with the nitrogen fertilization recommendation for maize in Rio Grande do Sul based on the soil organic matter content, predecessor crop and yield expectancy [15]. The source of $\mathrm{N}$ was urea $\left(\mathrm{CO}\left(\mathrm{NH}_{2}\right)_{2}\right)$. Complementary fertilization with a fixed dose was performed in the breeding stage.

For growth assessments, successive collections of three plants per plot were made at regular intervals of 21 days after sowing (DAS), throughout the development cycle, totally seven collection seasons. In each collection, the plants were separated into different structures (aerial part, root, stem, tassel and spikes), and the roots were washed using a fine-mesh sieve. The different structures were conditioned separately in brown paper envelopes and subjected to oven drying with forced ventilation at a temperature of $70^{\circ} \mathrm{C} \pm 2^{\circ} \mathrm{C}$ until reaching a constant mass.

The leaf area (Af) was determined with the aid of an area meter, model LI3100, and the leaf area index (L) calculated using the equation $\mathrm{L}=\mathrm{Af} / \mathrm{St}$, where St corresponds to the superficial area occupied by the plant. The total dry matter data over time $(\mathrm{Wt})$ was adjusted using the simple logistic equation $\mathrm{Wt}=$ $\mathrm{Wm} /(1+\mathrm{Ae}-\mathrm{Bt})$, where $\mathrm{Wm}$ is the asymptotic maximum growth estimate, " $\mathrm{A}$ " and "B", "And" the natural basis of Napierian logarithm and " $t$ " the time in days 

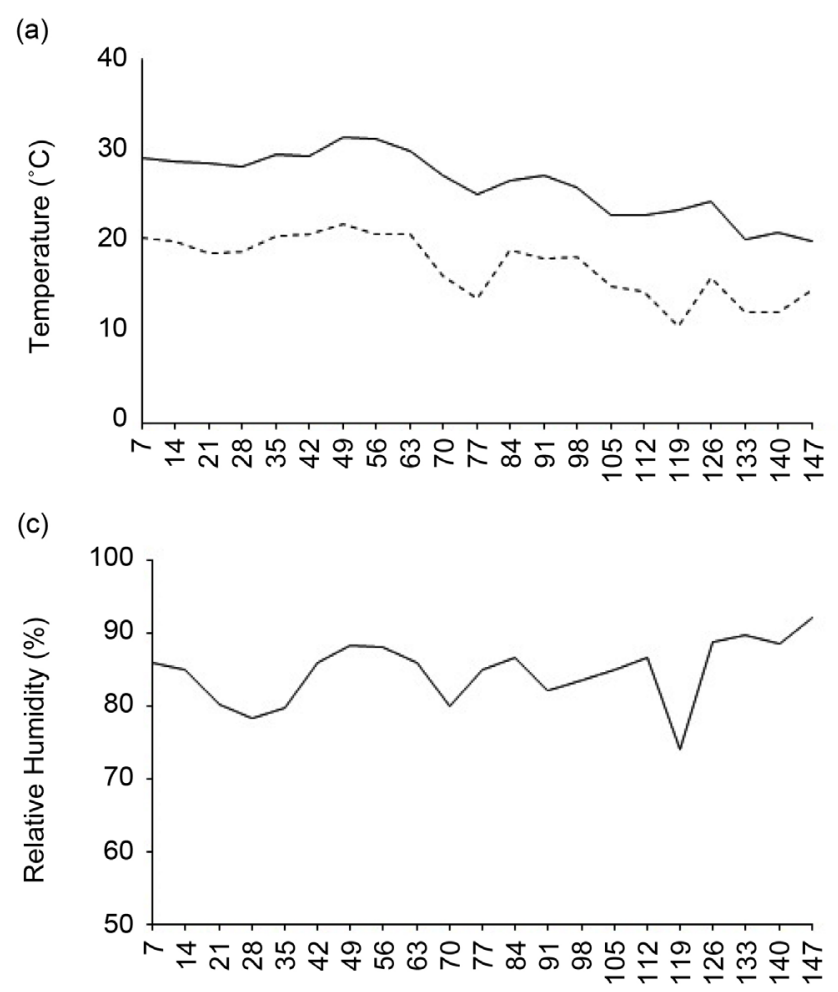

Days after sowing

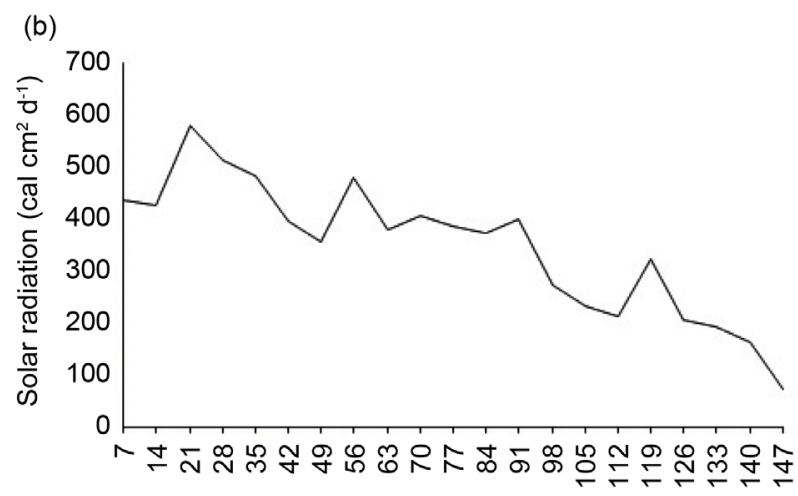

(d)

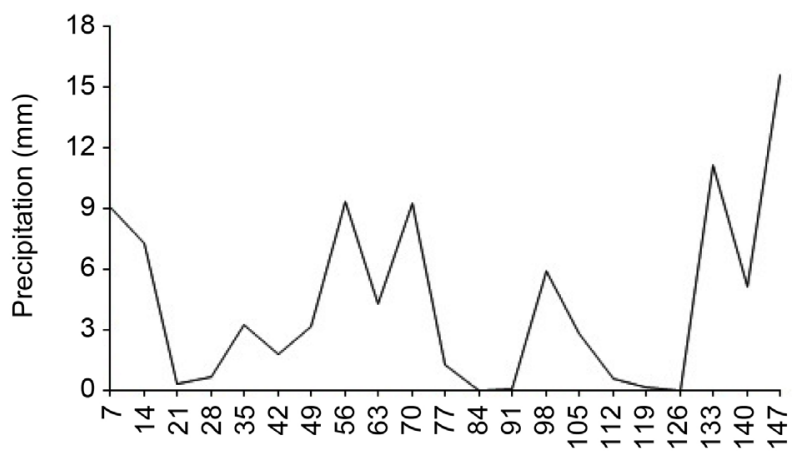

Days after sowing

Figure 1. Maximum (-) and minimum (---) temperatures (a), solar radiation (b), relative humidity (c) and precipitation (d). 
Nakagawa [20]. Together with the emergence of seedlings in soil, the emergence velocity was evaluated from the daily number of emerged seedlings until stabilization. The counts were performed until a constant number of seedlings emerged, and the results were obtained in accordance with Nakagawa [20].

A mass of 1000 seeds was determined by a mass of 100 seeds from the experimental plot area, counted at random with the aid of a manual counter, then measured using a precision scale, using eight subsamples per plot.

The experimental design was a randomized complete block design in a $4 \times 7$ factorial scheme (four $\mathrm{N}$ rates at soil seeding and seven collection times with three replications). The total dry matter data were analyzed by the simple logistic equation and the discussion was based on the trend of the growth curves [12]. The vigor data were submitted to a randomized experimental design with eight replications. Assimilated partition data were converted to percentage of dry matter allocated in each evaluated plant structure, and those referring to primary growth data were submitted to analysis of variance. The data related to vigor when significant at $5 \%$ probability were represented by orthogonal polynomials, using the WinSTAT statistics software.

\section{Results and Discussion}

A significant interaction was observed at the probability level of 5\% for the primary data of leaf area, dry matter of stalk, dry matter of roots and dry matter of ears of maize plants submitted to the influence of different doses of nitrogen $(\mathrm{N})$ at sowing. The production of total dry matter $(\mathrm{Wt})$ in maize plants under different $\mathrm{N}$ rates at sowing presented a logistic tendency with a high coefficient of determination $\left(R^{2} \geq 0.87\right)$. Maize plants presented slow growth until 42 days after sowing (DAS), with rapid growth after this period, presenting a maximum growth at 147 DAS (Figure 2(a), Table 1).

Table 1. Summary of variance analysis with mean squares for primary leaf area (Af), leaf dry matter (Wf), stem (Wc), root (Wr) and ear (Wesp) dry matter. Capão do Leão, UFPel, 2017.

\begin{tabular}{ccccccc}
\hline \multirow{2}{*}{ FV } & DF & \multicolumn{5}{c}{ Medium Squares } \\
\cline { 3 - 7 } & & $\mathrm{A}_{\mathrm{f}}$ & $\mathrm{W}_{\mathrm{f}}$ & $\mathrm{W}_{\mathrm{c}}$ & $\mathrm{W}_{\mathrm{r}}$ & $\mathrm{W}_{\text {esp }}$ \\
\hline Doses (D) & 3 & $4,773,625^{*}$ & $669.29^{*}$ & $98.15016^{*}$ & $1544.98^{*}$ & $368.11^{*}$ \\
Seasons (S) & 6 & $1.66 \mathrm{E} 007^{*}$ & $3547.95^{*}$ & $1904.801^{*}$ & $2105.82^{*}$ & $32,448.07^{*}$ \\
Block & 2 & $22,328.16$ & 2.15 & 2.030781 & 0.3399 & 16.29 \\
D x E & 18 & $701,411.90^{*}$ & $85.33^{*}$ & $63.64213^{*}$ & $291.26^{*}$ & $137.16^{*}$ \\
Residue & 54 & $14,770.11$ & 0.9600 & 1.368481 & 0.7865 & 5.66 \\
Total & 83 & - & - & - & - & - \\
Average & & 2128.68 & 28.59 & 18.11 & 18.79 & 31,93 \\
CV (\%) & & 5.7 & 3.42 & 6,45 & 4.71 & 7.45 \\
\hline
\end{tabular}

Level of significance $\left({ }^{*} \mathrm{p}=5 \%\right)$ and not significant $(\mathrm{ns})$. 

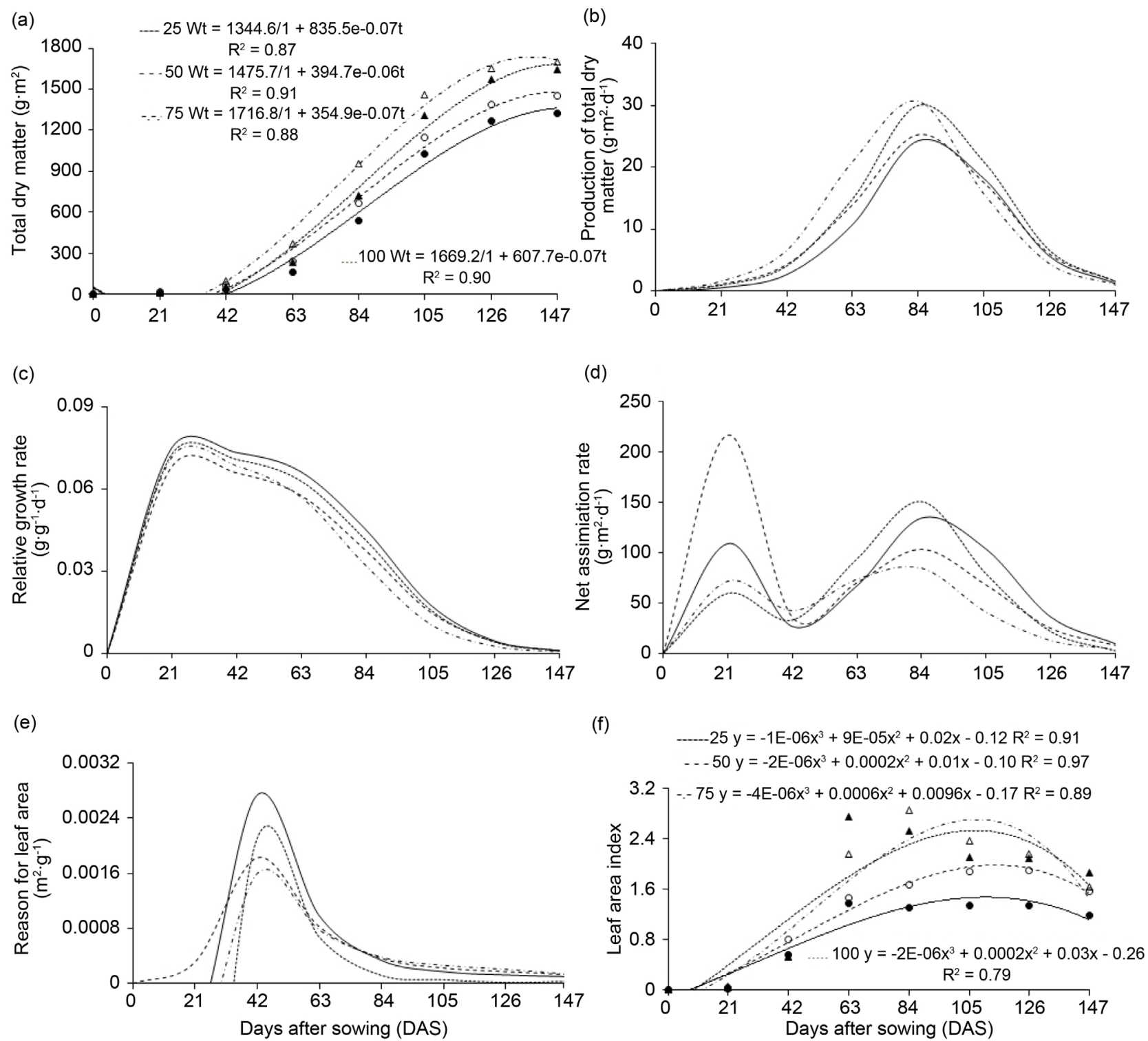

Figure 2. Total dry matter (a), dry matter production rate (b), relative growth rate (c), net assimilation rate (d), leaf area index (e) and leaf area ratio of maize plants ( $Z$. mays L.) submitted to different doses of $\mathrm{N}$ at sowing. $25 \%$ of the recommended dose ( - ), $50 \%$ of the recommended dose $(---)$, $75 \%$ of the recommended dose $(\cdot-\cdot)$ and $100 \%$ of the recommended dose $(\cdots \cdots)$ for the culture.

The use of $\mathrm{N}$ doses at sowing increased $\mathrm{Wt}$ at doses of $75 \%, 100 \%, 50 \%$ and $25 \% \mathrm{~N}$, reaching $1702.87,1647.99,1453.19$ and $1327.37 \mathrm{~g} \cdot \mathrm{m}^{-2}$, respectively. The differences between dry matter accumulations of $75 \%$ and $100 \%$ doses in relation to the others may be related to the higher initial availability of $\mathrm{N}$ for growth, while the doses of $5 \%$ and $25 \%$ were not sufficient for large dry matter additions.

The higher accumulation of dry matter obtained in the $75 \%$ dose can be related to the high net assimilated production [21] by the maize plants, since the $\mathrm{N}$ in the plant acts by participating in the molecules of organic compounds. In addition, the negative effect of a high $\mathrm{N}$ dose on sowing on initial plant performance may be a consequence of the phytotoxic effect of high doses of fertilizer 
on seedling emergence [22] [23].

The maximum dry matter $(\mathrm{Ct})$ production rate was reached at approximately 84 DAS for the $\mathrm{N}$ rates at sowing (Figure $1(\mathrm{~b})$ ). Plants at $75 \% \mathrm{~N}$ had higher $\mathrm{Ct}$ than plants under $100 \%, 50 \%$ and $25 \% \mathrm{~N}$, showing greater efficiency in the increase of dry matter per unit area in relation to time. Similar trends were found by Pedó et al. [24] in rye plants and by Koch et al. [25] in wheat.

The increase in the dry matter production rate can be attributed to the increase in the leaf area and the amount of assimilates synthesized, destined to the growth and the vegetal development, due to the greater availability of the element in the initial stages in pepper [26]. On the other hand, the subsequent decrease in $\mathrm{Ct}$ is related to the increase in plant age and nonphotosynthetic tissues in beans [27].

The relative growth rate $(\mathrm{Rw})$ of maize plants under different $\mathrm{N}$ rates at sowing showed maximum values at 21 DAS, with a subsequent decrease up to 147 DAS (Figure 2(c)). The maximum values of $\mathrm{Rw}$ were obtained by plants at $25 \%$ $\mathrm{N}$, followed by doses of $100 \%, 75 \%$ and $50 \% \mathrm{~N}$, demonstrating that increasing $\mathrm{N}$ rates at sowing influenced Rw. According to Aumonde et al. [21], the high initial Rw can be attributed to the high photosynthetic capacity of the leaves at the beginning of plant growth, and according to Lopes et al. [28] its decrease is due to auto-shading.

The growth of the plant in terms of volume increase, dry mass, linear dimensions and structural units is a function of the storage of structural carbon [21]. In this sense, the increase in initial growth may be associated with greater availability of the element in the early stages of cultivation. The net assimilation rate (Ea) in maize plants submitted to different doses of $\mathrm{N}$ at sowing presented the best results with $50 \%$ of the $\mathrm{N}$ dose recommended at $21 \mathrm{DAS}$ in relation to the other doses (Figure 2(d)). At 21 DAS, the highest values were found at doses of $50 \%, 25 \%, 75 \%$ and $100 \%$, at the beginning of the vegetative growth, with a subsequent decrease at these doses. At 84 DAS the second peak was found for doses of $100 \%, 25 \%, 50 \%$ and $75 \%$, respectively. According to Gondim et al. [29], the Ea tends to be higher at the beginning of the cycle when auto-shading is low and, according to Lopes et al. [28], the second peak is attributed to the beginning of the reproductive phase of the plants.

It is possible that plants at the highest $\mathrm{N}$ doses reached the greatest difference between crude photosynthesis and respiration, resulting in higher total dry matter production. In this sense, the highest Ea are related to the increase of the efficiency of the leaf area for photoassimilate production, with the second Ea peak being due to the emergence of the plant reproductive structures [30]. Ea curves showing two peaks during plant ontogeny have been described by Silva et al. [31] in barley, Falqueto et al. [32] in rice and Pedó et al. [24] in rye.

The leaf area index (L) was adjusted to the cubic model, with a high coefficient of determination $\left(\mathrm{R}^{2} \geq 0.92\right)$. At the beginning of the growth the $\mathrm{L}$ was reduced and reached the maximum near 105 DAS (Figure 2(e)) with a subsequent 
decrease. The highest values of $\mathrm{L}$ were obtained by maize plants at the $75 \%$ dose followed by $100 \%, 50 \%$ and $25 \%$ doses. Aumonde et al. [21] reported that the decrease in $\mathrm{L}$ at the end of the cycle is a result of foliar senescence. The $\mathrm{L}$ is a growth variable that indicates the leaf surface in relation to the soil surface, and according to Peixoto and Peixoto [33], L is responsible for the interception of solar energy.

It can be seen that the application of $\mathrm{N}$ at sowing exerted a positive influence on L, providing an increase in the area of the soil occupied by leaves. An adequate supply of $\mathrm{N}$ is considered one of the main factors in the maize crop, since this nutrient exerts an important function in the biochemical processes of the plant. In addition, it affects leaf initiation and expansion rates, leaf size and leaf senescence intensity [34].

The maximum leaf area ratio $(\mathrm{Fa})$ was reached at $42 \mathrm{DAS}$ for all $\mathrm{N}$ rates, with subsequent decreases up to 147 DAS (Figure 2(f)). The highest values were obtained at the dose of $25 \%$ followed by the doses of $100 \%, 50 \%$ and $75 \%$. According to Peixoto and Peixoto [33], the decrease in Fa is due to self-shading, caused by the upper leaves above the lower ones [35]. A similar trend was found by Koch et al. [25] when evaluating the effect of growth regulator doses on wheat plants under high nitrogen fertilization rates.

The leaf mass ratio $(\mathrm{Fw})$ of maize plants was high at $42 \mathrm{DAS}$ for both $\mathrm{N}$ rates at sowing. The $100 \% \mathrm{~N}$ dose presented the highest leaf dry matter allocation at 42 DAS, followed by $50 \%, 75 \%$ and $25 \% \mathrm{~N}$ at sowing (Figure $3(\mathrm{a})$ ), with a subsequent decrease at all doses. The use of $100 \% \mathrm{~N}$ at sowing reflected an accumulation of approximately $68 \%$ more leaf dry matter, compared to the $25 \% \mathrm{~N}$ dose at sowing.

The conversion efficiency of solar energy $(\xi)$ showed increasing peaks up to 105 DAS (Figure 3(b)), with maximum values of $3.55 \%, 3.40 \%, 3.72 \%$ and $4.06 \%$ for plants at $25 \%, 50 \%, 75 \%$ and $100 \% \mathrm{~N}$ at sowing, respectively, with a subsequent decline to 147 DAS. $\xi$ presented a high peak at 84 DAS, together with the maximum obtained at $\mathrm{Ct}$ (Figure 2(b)). Up to 84 DAS, the dose of $75 \%$ of $\mathrm{N}$ presented greater $\xi$ than the other doses, whereas at 105 DAS the highest $\xi$ was obtained at doses of $100 \% \mathrm{~N}$ at sowing. $\xi$ is a variable that relates the production of dry matter in energy units [36], reflecting the highest total dry matter allocation at $75 \% \mathrm{~N}$ at sowing.

Increasing the dose of $\mathrm{N}$ applied, most of the time, provides an increase in the structures and increases the yield of the crop [37]. Nitrogen fertilization in maize showed a positive effect on leaf area index and the number of seeds/ears at plant height, as well as on biomass yield [38]. Similar trends of $\xi$ were found in works with beans by Reyes-Cuesta et al. [27], with soybean by Melges et al. [39], Marenco and Lopes [40] and with wheat by Koch et al. [25].

There was similarity in the dry matter partition between the $50 \%$ and $75 \% \mathrm{~N}$ rates in the sowing of maize plants (Figure 3(d), Figure 3(e)). However, $75 \% \mathrm{~N}$ plants show less leaf dry matter allocation and higher roots in the range of 63 to 

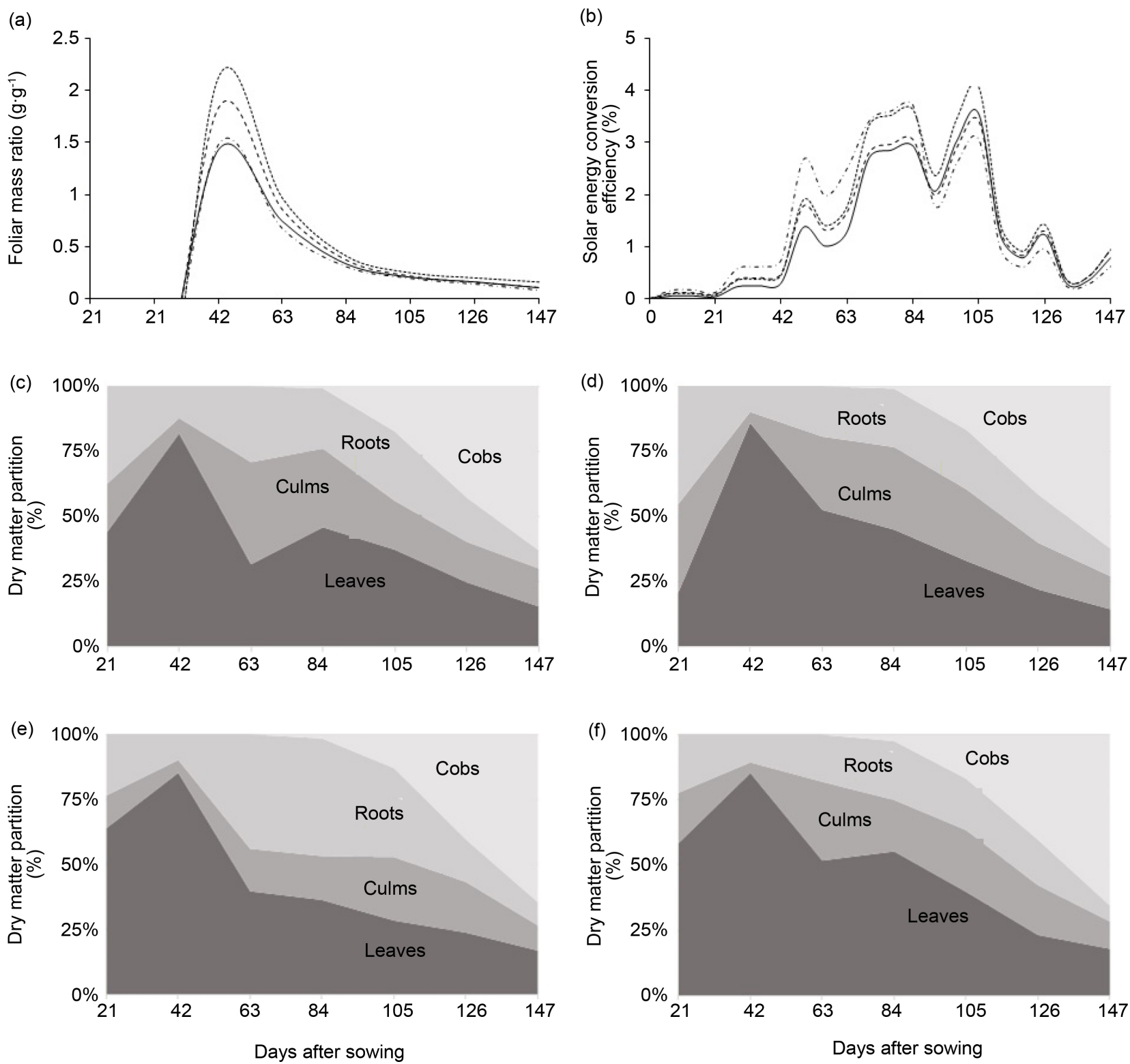

Figure 3. Foliar mass ratio (a), conversion efficiency of solar energy (b) of maize plants ( $Z$. mays L.) submitted to different doses of $\mathrm{N}$ at sowing. $25 \%$ of the recommended dose $(-), 50 \%$ of the recommended dose $\left(---^{-}\right), 75 \%$ of the recommended dose $(\cdot-\cdot)$ and $100 \%$ of the recommended dose ( …..) for the culture. And dry matter partition of different structures of maize plants ( $Z$. mays L.) submitted to different doses of $\mathrm{N}$ at sowing. $25 \%$ of the recommended dose (c), $50 \%$ of the recommended dose (d), $75 \%$ of the recommended dose (e) and $100 \%$ of the recommended dose (f) for the culture.

105 DAS than $50 \% \mathrm{~N}$ roots. Although nutritional requirements are lower in the early stages [10]. In addition, the high $\mathrm{N}$ concentrations in the root zone are beneficial in promoting rapid initial plant growth and root growth [10] [41].

The use of the $100 \% \mathrm{~N}$ dose at sowing increased the leaf dry matter partition up to 84 DAS (Figure 3(f)), while reducing the root partition. It is worth noting that, due to the increase in the dry matter partition in leaves during the development cycle, the accumulation in the other structures was altered, which can cause structural problems and the lodging of maize plants along the ontogeny 
[42]. The tests detected significant differences in seed physiological quality, and the emergence and emergence speed of maize seedlings from seeds produced under different $\mathrm{N}$ rates (Figure 4).

Seedling emergence tended to increase with increasing doses of $\mathrm{N}$ (Figure $4(\mathrm{a})$ ), adjusting in a quadratic model, with a determination coefficient of $\mathrm{R}^{2} \geq$ 0.70 . Thus, the expression of maize seed vigor was positively influenced by the $\mathrm{N}$ increase. At doses higher than the point of maximum technical efficiency $(82.5 \%)$ there was a tendency for the emergence to reduce. At the emergence speed, the maximum technical efficiency is $58 \%$ of the dose of $\mathrm{N}$, which presents the fastest emergence of seedlings (Figure $4(\mathrm{~b})$ ). The highest quality at these doses probably occurs because nitrogen fertilization interferes with protein content and may affect seed quality [43], since the reserve proteins are hydrolyzed during the germination of the seeds to supply $(\mathrm{N}$, sulfur and carbon skeletons the embryonic axis and the seedlings during the early stages of development) [44].

The harvest index (Hi) was adjusted to the quadratic model, with a determination coefficient of $\mathrm{R}^{2} \geq 0.95$. The Hi indicates higher carbon allocation in the seeds in relation to the total dry matter of the plants. From the $50 \% \mathrm{~N}$ dose at sowing the Hi was elevated (Figure 4(c)). In this sense, the carbon allocation is related to the availability of $\mathrm{N}$ for the physiological and biochemical processes in the early stages of the crop. Similar results were obtained by Gava et al. [45] in maize, with an increase of $\mathrm{N}$ in the highest $\mathrm{N}$ rates, evidencing that there was a

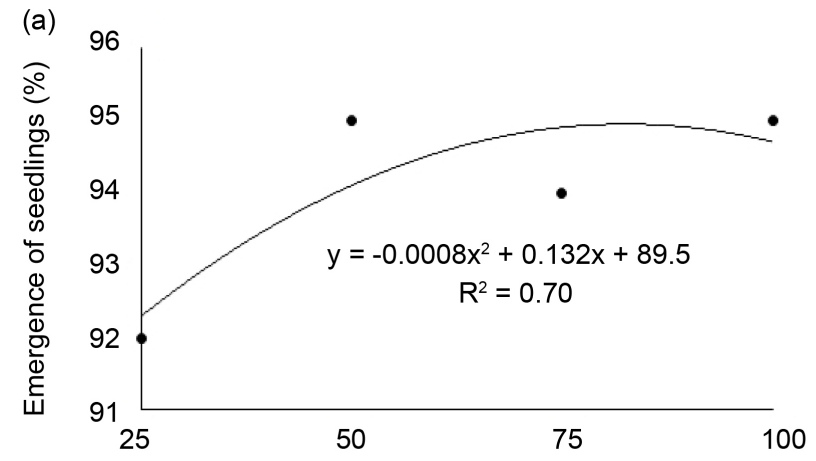

(c)

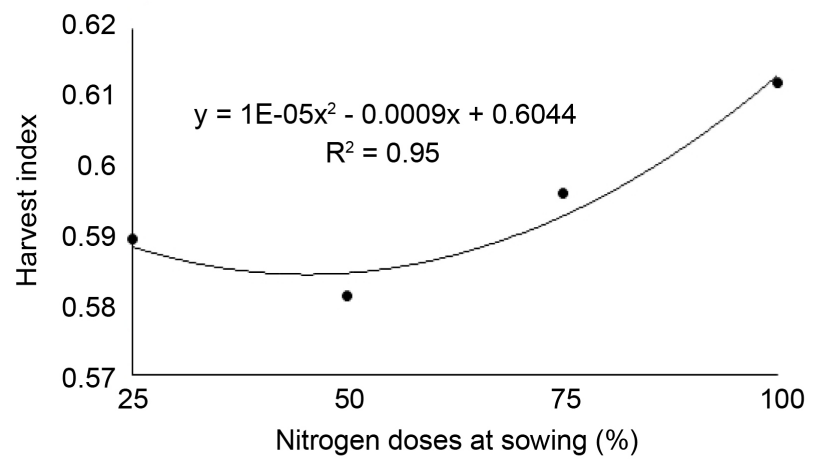

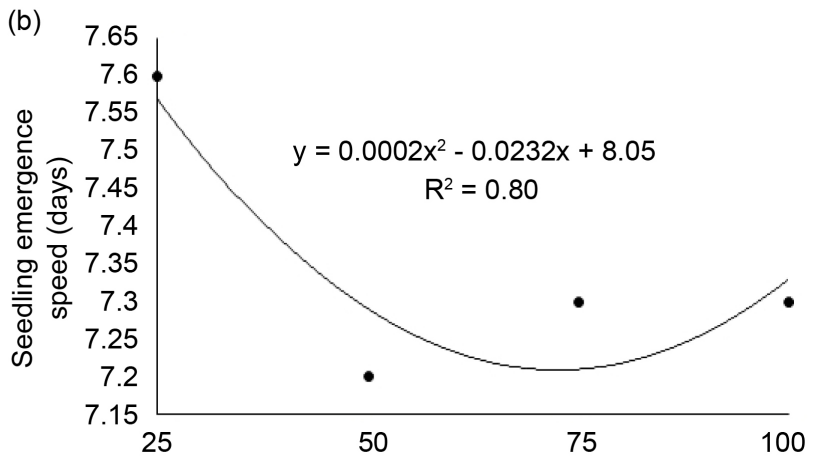

(d)

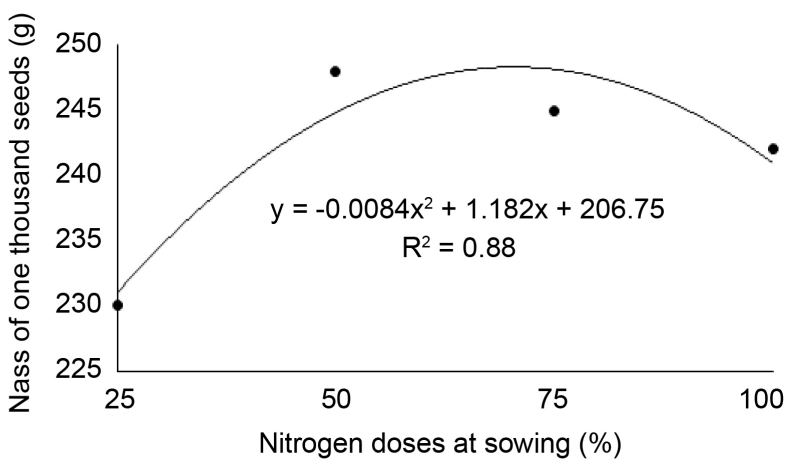

Figure 4. Emergence (a), seedling emergence velocity (b), crop index (c) and mass of one thousand maize ( $Z$. mays L.) seeds originated from plants submitted to different doses of $\mathrm{N}$ in seeding. 
good translocation of photoassimilates from the leaves to the grains, that is, the efficiency of the conversion of phytomass to grains was satisfactory.

The use of this index allows us to identify the ability of a genotype to combine high total production capacity and to allocate the accumulated dry matter to components of economic interest, in this case grain/seed production [46]. According to the same authors, the grain harvest index can vary from 0.60 for cultivars of high productivity to 0.10 for cultivars of low productivity. Consequently, the results of $\mathrm{Hi}$ obtained demonstrate an increase in total production as the dose of $\mathrm{N}$ fertilization in the base increases.

The mass of 1000 seeds responded to the application of $\mathrm{N}$ doses adjusting to the quadratic function (Figure $4(\mathrm{~d})$ ), increasing to the point of maximum technical efficiency (70.36\% of the $\mathrm{N}$ dose) with a subsequent reduction. According to Escosteguy et al. [47], $\mathrm{N}$ determines the development of maize plants with a significant increase in leaf area and dry matter production, resulting in higher grain yield. This is confirmed by observing the relationship between the application of $\mathrm{N}$ and the mass of 1000 seeds observed in Figure 4(d). Similar results were observed by Queiroz et al. [48] and Maestrelo et al. [7].

The reduction of the mass of 1,000 seeds from the point of maximum technical efficiency is possibly related to the fact that an increase in the accumulation of dry phytomass occurs, thereby increasing the maintenance breath and, consequently, reducing the translocation of photoassimilates to the grains. In general, the dry matter yield of a crop is closely related to L and Ea [39]. The maximum $\mathrm{Ct}$ is related to the maximum $\xi$ (Figure 2(a)). However, the Ea in maize plants submitted to different doses of $\mathrm{N}$ at sowing presented the best results with $50 \%$ of the recommended dose, being related to $L$ and together with the sending of photoassimilates to reproductive organs [28].

It was possible to demonstrate that in maize plants under the rate of $75 \%$ of $\mathrm{N}$ at sowing, they obtained higher $\mathrm{Wt}$ and $\mathrm{Ct}$, while at the dose of $100 \%$ of $\mathrm{N}$ a higher Fw was shown. According to Aumonde et al. [21], Fw provides an estimate of the fraction of assimilates retained in the leaves and not exported to the other organs of the plant, reflecting the mass and vigor of the seeds with the highest $\mathrm{N}$ rates at sowing. In this sense, the reduction of the percentage of dry matter in roots under the effect of doses of $\mathrm{N}$ possibly occurred as a result of the increase of greater allocation of dry matter in the reproductive structures, aimed at greater allocation of carbon in the spikes.

\section{Conclusions}

Maize plants under the influence of nitrogen fertilization at sowing present differential responses in the growth and partition of assimilation between their structures, with the intensity depending on the dose used.

Plants under the effect of applying $75 \%$ of the recommended dose of $\mathrm{N}$ at sowing have a higher relative growth rate, with more pronounced effects than the other doses. The vigor expression of maize seeds increased up to $82.5 \% \mathrm{~N}$ at sowing. 


\section{References}

[1] Teixeira, L.R., Braccini, A.L., Sperandio, D., Scapim, C.A., Schuster, I. and Viganó, J. (2008) Avaliação de cultivares de soja quanto à tolerância ao estresse hídrico em substrato contendo polietileno glicol. Acta Scientiarum Agronomy, 30, 217-223. https://doi.org/10.4025/actasciagron.v30i2.1731

[2] Fancelli, A.L. and Dourado-Neto, D. (1999) Tecnologia da produção de milho. FEALQ/ESALQ/USP, Piracicaba.

[3] Fornasieri-Filho, D. (2007) Manual da cultura do milho. Funep, Jaboticabal.

[4] Niklas, K.J. (2006) Plant Allometry, Leaf Nitrogen and Phosphorus Stoichiometry and Interspecific Trends in Annual Growth Rates. Annals of Botany, 97, 155-163. https://doi.org/10.1093/aob/mcj021

[5] Diatloff, E., Smith, F.W. and Asher, C.J. (2008) Effects of Lanthanum and Cerium on the Growth and Mineral Nutrition of Corn and Mungbean. Annals of Botany, 101, 971-982. https://doi.org/10.1093/aob/mcn021

[6] Zucareli, C., Alves, G.B., Oliveira, M.A. and Machado, M.H. (2014) Desempenho agronômico do milho safrinha em resposta às épocas de aplicações e fontes de nitrogênio. Científica, 42, 60-67. https://doi.org/10.15361/1984-5529.2014v42n1p60-67

[7] Maestrelo, P.R., Buzetti, S., Teixeira Filho, M.C.M., Garcia, C.M.P., Rodrigues, M.A.C., Lino, A.C.M. and Andreotti, M. (2014) Aplicação de ureia revestida em cobertura no milho irrigado sob sistema de semeadura direta. Revista Brasileira de Ciências Agrárias, 9, 192-199. https://doi.org/10.5039/agraria.v9i2a3708

[8] Malavolta, E. (2006) Manual de nutrição mineral de plantas. Editora Ceres, Piracicaba.

[9] Sangoi, L., Ernani, P.R., Silva, P.R.F. da., Horn, D., Schmitt, A. and Schweitzer, C. (2006) Desempenho agronômico de cultivares de milho em quatro sistemas de manejo. Revista Brasileira de Milho e Sorgo, 5, 218-231.

https://doi.org/10.18512/1980-6477/rbms.v5n2p218-231

[10] Yamada, T.(1996) Adubação nitrogenada do milho: Quanto, como e quando aplicar? Potafós, Piracicaba.

[11] Marschner, H. (1995) Mineral Nutrition of Higher Plants. Academic Press, San Diego.

[12] Lopes, N.F. and Lima, M.G. de S. (2015) Fisiologia da produção vegetal. UFV, Viçosa.

[13] Peske, S.T., Villela, F.A. and Meneghello, G.E. (2012) Sementes: Fundamentos Científicos e Tecnológicos. Editora Universitária/UFPel, Pelotas.

[14] Borghi, E. and Crusciol, C.A.C. (2007) Produtividade de milho, espaçamento e modalidade de consorciação com Brachiaria brizantha no SPD. Pesquisa Agropecuária Brasileira, 42, 163-171. https://doi.org/10.1590/S0100-204X2007000200004

[15] CQFS-RS/SC_Comissão de Química e Fertilidade do Solo RS/SC (2004) Manual de Adubação e de Calagem para o Estado do Rio Grande do Sul e Santa Catarina. SBCS/Núcleo Regional Sul, UFRGS, Porto Alegre.

[16] Streck, E.V., Kämpf, N., Dalmolin, R.S.D., Klamt, E., Nascimento, P.C., Schneider, P., Giasson. E. and Pinto, L.F.S. (2008) Solos do Rio Grande do Sul. EMATER/RS, Porto Alegre.

[17] Richards, F.J. (1969) The Quantitative Analysis of Growth. In: Stewward, F.C., Ed., Plantphysiology, Academic Press, New York, 3-76. 
https://doi.org/10.1016/B978-0-12-395516-6.50011-5

[18] Radford, P.J. (1967) Growth Analysis Formulae: Their Use and Abuse. Crop Science, 7, 171-175. https://doi.org/10.2135/cropsci1967.0011183X000700030001x

[19] Protásio, T.P., Bufalino, L. and Tonoli, G.H.D. (2011) Relação entre o poder calorífico superior e os Componentes elementares da biomassa. Pesquisa Florestal Brasileira, 3, 113-122. https://doi.org/10.4336/2011.pfb.31.66.113

[20] Nakagawa, J. (1994) Testes de vigor baseados na avaliação de plântulas. In: Vieira, R.D. and Carvalho, N.M., Eds., Testes de vigor em sementes, FUNEP, Jaboticabal, 49-85.

[21] Aumonde, T.Z., Lopes, N.F., Moraes, D.M., Peil, R.M.N. and Pedó, T. (2011) Análise de crescimento do híbrido de mini melancia Smile(r) enxertada e não enxertada. Interciencia, 36, 677-681.

[22] Rodrigues, J.R.M., Andrade, M.J.B., Carvalho, J.G., Morais, A.R. and Rezende, P.M. (2002) População de plantas e rendimento de grãos do feijoeiro em função de doses de nitrogênio e fósforo. Ciência e Agrotecnologia, 26, 1218-1227.

[23] Kikuti, H., Andrade, M.J.B., Carvalho, J.G. and Morais, A.R. (2005) Nitrogênio e fósforo em feijão (Phaseolus vulgaris L.) variedade cultivada BRS MG Talismã. Acta Scientiarum, 27, 415-422. https://doi.org/10.4025/actasciagron.v27i3.1402

[24] Pedó, T., Martinazzo, E.G., Aumonde, T.Z. and Villela, F.A. (2015) Plant Growth Analysis and Seed Vigor Expression: Effects of Soil Waterlogging during Rye Plant Development. Acta Botanica Brasilica, 29, 1-7. https://doi.org/10.1590/0102-33062014abb3574

[25] Koch F., Aisenberg, G.R., Monteiro, M.A., Pedó, T., Zimmer P.D., Villela, F.A. and Aumonde, T.Z. (2017) Growth of Wheat Plants Submitted to the Application of the Growth Regulator Trinexapac-Ethyl and Vigor of the Produced Seeds. Agrociencia Uruguay, 21, 24-32.

[26] Pedó, T., Aumonde, T.Z., Lopes, N.F., Villela, F.A. and Mauch, C.R. (2013) Análise comparativa de crescimento entre genótipos de pimenta cultivados em casa de vegetação. Bioscience Journal, 29, 125-131.

[27] Reyes-Cuesta, R., Lopes, N.F., Oliva, M.A. and Franco, A.A. (1995) Crescimento e conversão da energia solar em Phaseolus vulgares em função da fonte de nitrogênio. Revista Ceres, 42, 405-455.

[28] Lopes, N.F., Oliva, M.A., Cardoso, M.J., Gomes, M.M.S. and Souza, V.F. (1986) Crescimento e conversão da energia solar em Phaseolus vulgares L. submetido a três densidades de fluxo radiante e dois regimes hídricos. Revista Ceres, 33, 142-164.

[29] Gondim, A.R.O., Puiatti, M., Ventrella, M.C. and Cecon, P.R. (2008) Plasticidade anatômica da folha de taro cultivado sob diferentes condições de sombreamento. Bragantia, 67, 1037-1045. https://doi.org/10.1590/S0006-87052008000400028

[30] Urchei, M.A., Rodrigues, J.D. and Stone, L.F. (2000) Análise de crescimento de duas cultivares de feijoeiro sob irrigação, em plantio direto e preparo convencional. Pesquisa Agropecuária Brasileira, 35, 497-506. https://doi.org/10.1590/S0100-204X2000000300004

[31] Silva, R.N., Lopes, N.F., Duarte, G.L., Moraes, D.M. and Pereira, A.L.A. (2007) Analysis of the Growth of Hordeum vulgare L. Plants Subjected to Saline Stress. Revista Brasileira Agrociência, 13, 455-463.

[32] Falqueto, A.R., Cassol, D., Magalhães Júnior, A.M., Oliveira, A.C. and Bacarin, M.A. (2009) Growth and Partition of Assimilates in Rice Crops Differing from the Grain Productivity Potential. Bragantia, 68, 563-571. 
https://doi.org/10.1590/S0006-87052009000300002

[33] Peixoto, C.P. and Peixoto, M.F.S.P. (2009) Dinâmica do crescimento vegetal: princípios básicos. In: Carvalho, C.A.L., Dantas, A.C.V.L., Pereira, F.A.C., Soares, A.C.F. and Melo Filho, J.F., Eds., Tópicos em Ciências Agrárias, Editora Nova Civilização, Cruz das Almas, 37-53.

[34] Schröder, J.J., Neeteson, J.J., Oenema, O. and Struik, P.C. (2000) Does the Crop or the Soil Indicate How to Save Nitrogen in Maize Production? Reviewing the State of Art. Field Crops Research, 66, 151-164. https://doi.org/10.1016/S0378-4290(00)00072-1

[35] Barreiro, A.P., Zucareli, A., Ono, E.O. and Rodrigues, J.D. (2006) Análise de crescimento de plantas de manjericão tratadas com reguladores vegetais. Bragantia, 65, 563-567. https://doi.org/10.1590/S0006-87052006000400005

[36] Lucchesi, A.A. (1984) Utilização prática da análise de crescimento vegetal. Anais da Escola Superior de Agricultura Luiz de Queiroz, 41, 181-202. https://doi.org/10.1590/S0071-12761984000100011

[37] Lantmann, A.F., Oliveira, E.L., Chaves, J.C.D. and Pavan, A. (1986) Adubação nitrogenada no Estado do Paraná. In: Santana, M.B.M., Ed., Adubação nitrogenada no Brasil, CEPLAC, Ilhéus, 19-46.

[38] Ulger, A.C., Becker, A.C. and Kant, G. (1995) Response of Various Maize Inbred Line and Hybrids to Increasing Rates of Nitrogen Fertilizer. Journal of Agronomy and Crop Science, 159, 157-163.

[39] Melges, E., Lopes, N.F. and Oliva, M.A. (1989) Crescimento e conversão da energia solar em soja cultivada sob quatro níveis de radiação solar. Pesquisa Agropecuária Brasileira, 24, 1065-1072.

[40] Marenco, R.A. and Lopes, N.F. (1998) Solar Radiation Conversion Efficiency and Growth of Soybean Plants Treated with Herbicides. Revista Ceres, 45, 265-275.

[41] Varvel, G.E., Schpers, J.S. and Francis, D.D. (1997) Ability for in Season Correction of Nitrogen Deficiency in Corn Using Chlorophyll Meters. Soil Science America Journal, 61, 1233-1239. https://doi.org/10.2136/sssaj1997.03615995006100040032x

[42] Von Pinho, R.G., Gross, M.R., Steola, A.G. and Mendes, M.C. (2008) Adubação nitrogenada, densidade e espaçamento de híbridos de milho em sistema de plantio direto na região sudeste de Tocantins. Bragantia, 67, 733-739. https://doi.org/10.1590/S0006-87052008000300023

[43] Lopez-Bellido, R.J., Shepherd, C.E. and Barraclough, P.B. (2004) Predicting Postanthesis $\mathrm{N}$ Requirements of Bread Wheat with a Minolta SPAD Meter. European Journal of Agronomy, 20, 313-320. https://doi.org/10.1016/S1161-0301(03)00025-X

[44] Imolesi, A.S., Pinho, E.V.R.V., Pinho, R.G.V., Vieira, M.D.G.G.C. and Corrêa, R.S.B. (2001) Influência da adubação nitrogenada na qualidade fisiológica das sementes de milho. Ciência e Agrotecnologia, 25, 1119-1126.

[45] Gava, G.J.C., Oliveira, M.W., Silva, M.A., Jerônimo, E.M., Cruz, J.C.S. and Trivelin, P.C.O. (2010) Produção de fitomassa e acúmulo de nitrogênio em milho cultivado com diferentes doses de 15N-uréia. Semina: Ciências Agrárias, 31, 851-862. https://doi.org/10.5433/1679-0359.2010v31n4p851

[46] Dourado Neto, D. and Fancelli, A.L. (2000) Produção de milho. Agropecuária, Guaíba.

[47] Escosteguy, P.A.V., Rizzardi, M.A. and Argenta, G. (1997) Doses e épocas de aplicação de nitrogênio em cobertura na cultura do milho em duas épocas de semeadura. Revista Brasileira de Ciência do Solo, 21, 71-77. 
[48] Queiroz, A.M., Souza, C.H., Machado, V.J., Lana, R.M.Q., Korndorfer, G.H. and Silva, A.A. (2011) Avaliação de diferentes fontes e doses de nitrogênio na adubação da cultura do milho (Zea mays L.). Revista Brasileira de Milho e Sorgo, 10, 257-266. https://doi.org/10.18512/1980-6477/rbms.v10n3p257-266 